\title{
Organic Geochemistry and Source Rock Potential of Naokelekan Formation in Selected Wells, North Iraq
}

\author{
Jan I. Ismael ${ }^{1}$
}

'Department of Geological Engineering, Faculty of Engineering, Selçuk University, Konya, Turkey Email:alturkmaniy@yahoo.com Tel:00905317668911

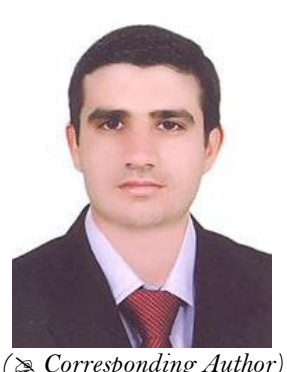

\begin{abstract}
In this study, organic geochemical characteristics and potential of Upper Oxfordian-Lower Kimmeridgian aged bituminous shale beds in Naokelekan formation (North Iraq) were investigated by using TOC and pyrolysis analyses. The Total Organic Carbon (TOC) contents for the studied samples varying between from $0.46-21.33 \%$, average $7.06 \%$ and Taq Taq-1 well as good hydrocarbon potential (0.85-1.66 \%, with average of $1.06 \%)$, whereas Jk-1 well can be rated as an very good hydrocarbon potential from 1.04-4.16\%, with average of $2.15 \%$. The low Hydrogen Index (HI = 24-605 mg HC/g TOC) for $\mathrm{Bj}-1$ well, $(\mathrm{HI}=147-673 \mathrm{mg} \mathrm{HC} / \mathrm{g}$ TOC$)$ in the Jk-1 well while in Taq Taq-1 well ( $\mathrm{HI}=9-48 \mathrm{mg} \mathrm{HC} / \mathrm{g}$ TOC) indicate that kerogen type for the vast majority of the studied samples is Type II/I for $\mathrm{Bj}-1$ well and Type IV with few samples, Type of I and II kerogens in the Taq Taq-1 and Jk-1 well. Consequently most of the organic matter of Bj-1 and Jk-1 well tends to generate petrol, even though a small portion of them exhibit a tendency to generate gas. While all samples of Taq Taq-1 well tends to generate gas. The studied bituminous rock samples characterized by low $\mathrm{T}_{\max }\left(434-602{ }^{\circ} \mathrm{C}\right)$ for Bj-1, Taq Taq-1 (344$\left.429{ }^{\circ} \mathrm{C}\right)$ and $\left(419-602{ }^{\circ} \mathrm{C}\right)$ for Jk-1 well. These values show, in terms of potential of hydrocarbon generation, that the studied samples have a source rock potential of organic matter from immature to over mature. Additionally, the $\mathrm{S}_{1}$ hydrocarbon type values indicate no external contribution of migrated hydrocarbons to the bituminous rocks of the studied area.
\end{abstract}

Keywords: Soruce rock, Rock Eval, Kerogen, Naokelekan formation, North Iraq.

Citation | Jan I. Ismael (2018). Organic Geochemistry and Source Rock Potential of Naokelekan Formation in Selected Wells, North raq. Asian Review of Environmental and Earth Sciences, 5(1): 8-14. History:

Received: 13 February 2018

Revised: 9 March 2018

Accepted: 12 March 2018

Published: 15 March 2018

Licensed: This work is licensed under a Creative Commons

Attribution 3.0 License $(\mathrm{ccc})$ EY

Publisher:Asian Online Journal Publishing Group
Funding: Author is grateful to the Selçuk University Research Fund for financial support (Project No: 16201040), and to the North oil company in Iraq for supplying well samples.

Competing Interests: The author declares that there are no conflicts of interests regarding the publication of this paper.

Transparency: The author confirms that the manuscript is an honest, accurate, and transparent account of the study was reported; that no vital features of the study have been omitted; and that any discrepancies from the study as planned have been explained.

Ethical: This study follows all ethical practices during writing.

\section{Contents}

1. Introduction 


\section{Introduction}

Rock-Eval pyrolysis has been a widely used method in organic geochemistry tool for examining the oil and gas potential and maturity of different rock samples. The available information concerning the TOC content, thermal maturation, and burial history are seriously required for better understanding of the existence of other hydrocarbon resources [1]. The dominant organic matter in oil shales is derived from one or more primary sources, the terrestrial plants, lacustrine algae and marine organisms. These include large lake basins of tectonic origin, small lakes, lagoons and shallow seas [2].

Naokelekan Formation one of the most important source rocks in Iraq. The Formation crops out mainly within the High Folded Zone of northern Iraq. Additionally, it is found within drilled oil wells of Low Folded Zone in Iraq Such as at Taq Taq, Jabal Kand and Biji oil fields.

50 core and cutting Samples from Naokelekan formation has been collected from Bj-1, Taq Taq-1 and Jk-1 wells and have been sent to Turkish TPAO Research Center / Petroleum Geochemistry Department (Ankara) to determine hydrocarbon potential for these samples by Rock Eval analysis, TOC (Total Organic Carbon) analysis and S1, S2, S3, Tmax, Oxygen İndex, Hydrogen İndex results for three wells.

\section{Geological Settings}

Oil Fields within the northern Iraq coincide with part of the Zagros Fold Belt and regionally extends within an elongated folded zone between the thrust zone in a triple junction boundary between Iran and Turkey with Iraq. Also, it extends towards the Mesopotamian Foredeep with Khleisya uplift towards the southwestern part of northern Iraq; well locations are plotted on location map of (Fig. 1) Locating this studied area is according to Buday [3]; Al-Sharhan and Nairn [4]; Sharland, et al. [5]; Aqrawi, et al. [6] and the Arabian Peninsula Basins map prepared by the US Geological Survey [7].

Tectonically, Iraq lies in the border area between the Arabian part of the African (Nubian-Arabian) Platform and the Asian branches of the Alpine Geosyncline. The platform of Iraqi territory is divided into two basic units, the Stable and Unstable Shelf. The Stable Shelf is characterized by reduced thickness of sedimentary cover and by the lack of folding. The Unstable Shelf has thick and folded sedimentary cover [3].

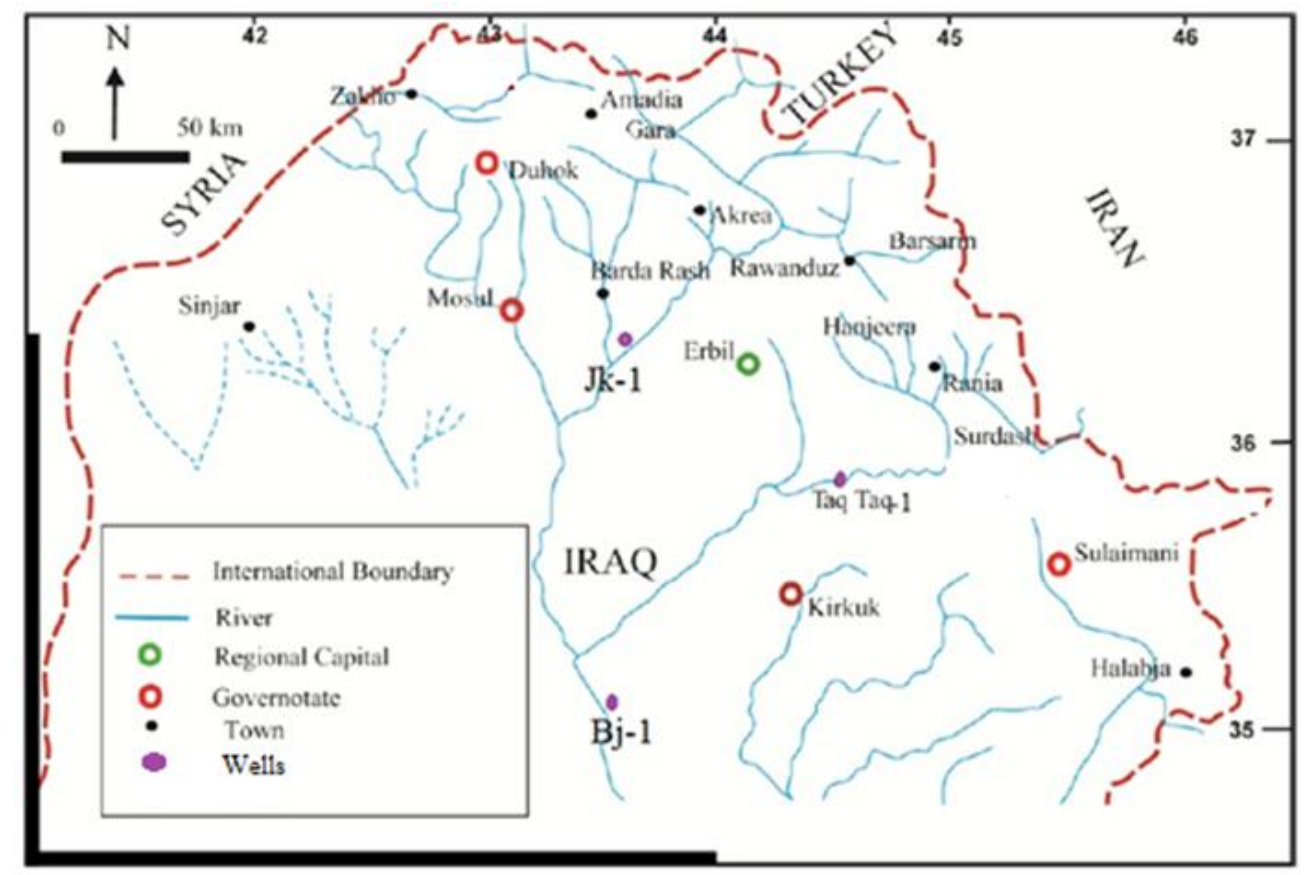

Fig-1. Location map of Iraq showing studied area of North Iraq with locations of oil exploration wells

Stratigraphically, Naokelekan Formation consists of laminated bituminous limestone, alternated with bituminous shale (coal horizon) and thin bedded, highly bituminous dolomite and limestone. Formation age is assigned as Upper Oxfordian-Lower Kimmeridgian according to the study of ammonites of the Upper Jurassic [8]. The depositional environment of the formation was interpreted as euxinic in a slow subsiding basin [3].

\section{Materials and Methods}

A total of 50 oil shale samples of the Naokelekan Formation were collected from 3 wells (Bj-1, Taq Taq-1 and Jk-1). These samples were crushed, pulverized and then homogenized. Rock-Eval pyrolysis was conducted using the Rock-Eval 6 analyzer manufactured by Vinci Technologies at the Geochemistry Laboratories of the Turkish Petroleum Corporation (TPAO). The analysis yielded several parameters, including S1, S2, S3, TOC and Tmax (Tables 1, 2, 3). Rock-Eval pyrolysis was conducted using the Rock-Eval 6 analyzer manufactured by Vinci Technologies at the Geochemistry Laboratories of the Turkish Petroleum Corporation (TPAO). The analysis yielded several parameters, including $\mathrm{S} 1, \mathrm{~S} 2, \mathrm{~S} 3$, TOC and Tmax (Tables 1, 2, 3). 
Table-1. Rock-Eval pyrolysis data are tabulated for the Naokelekan Formation in the Bj-1 well, North Iraq

\begin{tabular}{|c|c|c|c|c|c|c|c|c|c|}
\hline NO & $\begin{array}{l}\text { Depth } \\
\text { M }\end{array}$ & $\begin{array}{l}\text { TOC } \\
\%\end{array}$ & $\begin{array}{ll}\text { S1 } & \\
(\mathrm{mg} & \mathrm{HC} / \mathrm{g} \\
\text { Rock }) & \\
\end{array}$ & $\begin{array}{ll}\text { S2 } & \\
(\mathrm{mg} & \mathrm{HC} / \mathrm{g} \\
\mathrm{Roc}) & \\
\end{array}$ & $\begin{array}{l}\text { S3 } \\
(\mathrm{mg} \\
\text { Rock })\end{array}$ & PI & Tmax & $\begin{array}{l}\mathrm{HI}, \quad \mathrm{mg} \\
\mathrm{HC} / \mathrm{g} \\
\mathrm{TOC}\end{array}$ & $\begin{array}{l}\mathrm{OI}, \\
\mathrm{mg} \mathrm{CO} 2 / \mathrm{g} \\
\text { TOC }\end{array}$ \\
\hline 1 & 2383 & 1 & 0.77 & 4.19 & 0.61 & 0.15 & 434 & 419 & 61 \\
\hline 2 & 2384 & 1.11 & 0.83 & 4.55 & 0.38 & 0.15 & 434 & 410 & 34 \\
\hline 3 & 2385 & 3.05 & 2.33 & 18.49 & 0.78 & 0.11 & 435 & 605 & 26 \\
\hline 4 & 2386 & 2.88 & 1.17 & 10.5 & 0.72 & 0.1 & 435 & 365 & 25 \\
\hline 5 & 2387 & 1.99 & 0.57 & 5.45 & 0.84 & 0.09 & 430 & 278 & 42 \\
\hline 6 & 2388 & 1.12 & 0.4 & 3.78 & 0.66 & 0.1 & 435 & 338 & 59 \\
\hline 7 & 2389 & 0.46 & 0.24 & 0.96 & 0.39 & 0.2 & 426 & 209 & 85 \\
\hline 8 & 2391 & 5.26 & 0.99 & 24.47 & 1 & 0.04 & 441 & 465 & 19 \\
\hline 9 & 2392 & 5.44 & 1.14 & 19.49 & 1.07 & 0.06 & 438 & 358 & 20 \\
\hline 10 & 2393 & 2.26 & 0.68 & 8.15 & 0.77 & 0.08 & 438 & 361 & 34 \\
\hline 11 & 2394 & 0.92 & 0.33 & 2.35 & 0.5 & 0.12 & 431 & 255 & 54 \\
\hline 12 & 2401 & 22.89 & 2.02 & 119.72 & 2.97 & 0.02 & 441 & 523 & 13 \\
\hline 13 & 2402 & 15.91 & 1.66 & 82.18 & 2.64 & 0.02 & 442 & 517 & 17 \\
\hline 14 & 2403 & 13.64 & 1.47 & 68.02 & 2.87 & 0.02 & 441 & 499 & 21 \\
\hline 15 & 2404 & 21.03 & 1.54 & 107.79 & 4.2 & 0.01 & 442 & 513 & 20 \\
\hline 16 & 2405 & 19.35 & 1.36 & 91.79 & 3.41 & 0.01 & 440 & 474 & 18 \\
\hline 17 & 2407 & 10.37 & 1.1 & 47.61 & 3.61 & 0.02 & 441 & 459 & 35 \\
\hline 18 & 2409 & 13.3 & 1.47 & 67.92 & 2.18 & 0.02 & 442 & 511 & 16 \\
\hline 19 & 2410 & 13.64 & 1.3 & 68.52 & 1.91 & 0.02 & 442 & 502 & 14 \\
\hline 20 & 2411 & 11.96 & 1.4 & 64.62 & 2.08 & 0.02 & 442 & 540 & 17 \\
\hline 21 & 2412 & 8.94 & 1.05 & 44.05 & 1.22 & 0.02 & 439 & 493 & 14 \\
\hline 22 & 2413 & 6.07 & 0.86 & 29.19 & 1.39 & 0.03 & 439 & 481 & 23 \\
\hline 23 & 2414 & 3.59 & 0.55 & 16.54 & 0.87 & 0.03 & 439 & 461 & 24 \\
\hline 24 & 2432 & 1.19 & 0.3 & 2.07 & 0.6 & 0.13 & 437 & 174 & 50 \\
\hline 25 & 2433 & 1.08 & 0.4 & 0.43 & 0.6 & 0.48 & 581 & 40 & 56 \\
\hline 26 & 2434 & 3.39 & 0.88 & 1.21 & 0.83 & 0.42 & 583 & 36 & 24 \\
\hline 27 & 2435 & 2.79 & 0.68 & 0.92 & 0.63 & 0.42 & 579 & 33 & 23 \\
\hline 28 & 2436 & 7.67 & 1.09 & 2.81 & 0.85 & 0.28 & 585 & 37 & 11 \\
\hline 29 & 2437 & 5.58 & 0.89 & 1.82 & 0.94 & 0.33 & 584 & 33 & 17 \\
\hline 30 & 2438 & 9.91 & 1.03 & 2.91 & 1.35 & 0.26 & 594 & 29 & 14 \\
\hline 31 & 2439 & 9.54 & 1.03 & 2.7 & 1.33 & 0.28 & 595 & 28 & 14 \\
\hline 32 & 2440 & 3.42 & 0.65 & 0.87 & 0.88 & 0.43 & 597 & 25 & 26 \\
\hline 33 & 2441 & 2.29 & 0.46 & 0.56 & 0.63 & 0.45 & 602 & 24 & 28 \\
\hline
\end{tabular}

Table-2. Rock-Eval pyrolysis data are tabulated for the Naokelekan Formation in the Taq Taq-1 well, North Iraq

\begin{tabular}{|c|c|c|c|c|c|c|c|c|c|}
\hline NO & $\begin{array}{l}\text { Depth } \\
\text { M }\end{array}$ & ТОС\% & $\begin{array}{l}\text { S1 } \\
(\mathrm{mg} H C / g \\
\text { Rock) }\end{array}$ & $\begin{array}{l}\text { S2 } \\
(\mathrm{mg} \quad \mathrm{HC} / \mathrm{g} \\
\text { Rock })\end{array}$ & $\begin{array}{l}\text { S3 } \\
\text { (mg HC/g } \\
\text { Rock) }\end{array}$ & PI & Tmax & $\begin{array}{l}\text { HI, mg } \\
\mathrm{HC} / \mathrm{g} \\
\text { TOC }\end{array}$ & $\begin{array}{l}\mathrm{OI}, \\
\mathrm{mg} \mathrm{CO2} / \mathrm{g} \\
\text { TOC }\end{array}$ \\
\hline 1 & 2061 & 1.04 & 0.35 & 3.01 & 0.41 & 0.11 & 427 & 289 & 39 \\
\hline 2 & 2063 & 3.65 & 1.61 & 16.05 & 0.82 & 0.09 & 429 & 440 & 22 \\
\hline 3 & 2068 & 3.51 & 2 & 15.98 & 0.86 & 0.11 & 427 & 455 & 25 \\
\hline 4 & 2072 & 4.16 & 6.92 & 28 & 1.31 & 0.2 & 344 & 673 & 31 \\
\hline 5 & 2074 & 1.93 & 1.03 & 8.55 & 0.5 & 0.11 & 428 & 443 & 26 \\
\hline 6 & 2077 & 1.4 & 0.85 & 4.2 & 0.75 & 0.17 & 423 & 300 & 54 \\
\hline 7 & 2078 & 1.73 & 0.69 & 4.33 & 0.88 & 0.14 & 423 & 250 & 51 \\
\hline 8 & 2088 & 1.43 & 0.52 & 2.59 & 1.16 & 0.17 & 425 & 181 & 81 \\
\hline 9 & 2089 & 1.11 & 0.41 & 1.63 & 1.29 & 0.2 & 425 & 147 & 116 \\
\hline 10 & 2090 & 1.62 & 0.66 & 4.8 & 1.22 & 0.12 & 429 & 296 & 75 \\
\hline
\end{tabular}

Table-3. Rock-Eval pyrolysis data are tabulated for the Naokelekan Formation in the Jk-1 well, North Iraq

\begin{tabular}{|c|c|c|c|c|c|c|c|c|c|}
\hline NO & $\begin{array}{l}\text { Depth } \\
\text { M }\end{array}$ & ТОС\% & $\begin{array}{l}\text { S1 } \\
(\mathrm{mg} H C / g \\
\text { Rock })\end{array}$ & $\begin{array}{l}\text { So } \\
(\mathrm{mg} \quad \mathrm{HC} / \mathrm{g} \\
\text { Rock })\end{array}$ & $\begin{array}{l}\text { S3 } \\
(\mathrm{mg} \mathrm{HC} / \mathrm{g} \\
\text { Rock })\end{array}$ & PI & Tmax & $\begin{array}{l}\text { HI, } \quad m g \\
\text { HC/g TOC }\end{array}$ & 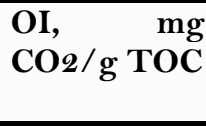 \\
\hline 1 & 3219 & 0.95 & 0.1 & 0.09 & 0.54 & 0.51 & 419 & 9 & 57 \\
\hline 2 & 3220 & 1.22 & 0.15 & 0.12 & 0.54 & 0.55 & 433 & 10 & 44 \\
\hline 3 & 3221 & 0.85 & 0.1 & 0.27 & 0.68 & 0.27 & 433 & 32 & 80 \\
\hline 4 & 3224 & 0.87 & 0.29 & 0.31 & 0.41 & 0.49 & 584 & 36 & 47 \\
\hline 5 & 3225 & 1.04 & 0.23 & 0.27 & 0.89 & 0.46 & 595 & 26 & 86 \\
\hline 6 & 3226 & 1.66 & 0.47 & 0.43 & 0.61 & 0.53 & 602 & 26 & 37 \\
\hline 7 & 3230 & 0.85 & 0.32 & 0.41 & 0.59 & 0.44 & 445 & 48 & 69 \\
\hline
\end{tabular}

A Flame İonization Detector (FID) was used to measure the concentration of organic compounds generated during pyrolysis. The first peak S1 represents hydrocarbons that can be thermally distilled from a rock. The second peak $\mathrm{S} 2$ represents hydrocarbons generated by the pyrolytic degradation of the kerogen in the rock. The third peak S3 stands for the carbon dioxide generated during temperature programming up to $390{ }^{\circ} \mathrm{C}$, and is analyzed using a Thermal Conductivity Detector (TCD). The Hydrogen Index (HI) corresponds to the quantity of pyrolyzable organic compounds from $\mathrm{S} 2$ relative to the TOC in the samples ( $\mathrm{mg} \mathrm{HC} / \mathrm{g}$ TOC) and can be successfully used to assess the oil generation potential of the rock and the type of organic matter. 


\section{Results and Discussions}

Pyrolysis techniques were used to establish the hydrocarbon potential and kerogen type as well as source rock type.

\subsection{Organic Matter Richness}

Total organic carbon analysis (TOC) describes the quantity of organic carbon in a rock sample including both kerogen and bitumen [9].

TOC of Naokelekan formation for $\mathrm{Bj}-1$ well show an excellent hydrocarbon potential (0.46-21.33\%, with an average of 7.06\%) and Taq Taq-1 well as good hydrocarbon potential (0.85-1.66 \%, with an average of $1.06 \%)$, additionally Jk-1 well show very good hydrocarbon potential (1.04-4.16\%, with an average of $2.15 \%$, Tables 1,2 , 3).

\subsection{Organic Matter Types}

The term kerogen is to designate organic constituents of sedimentary rocks that are neither soluble in aqueous alkaline solvents nor in the common organic solvents [10].

All organic matter particles generated from phytoplankton, zooplankton, remains of bacteria, and higher plants have been recognized as the main contributors to kerogen in sediments [10]. The minor amounts of substances soluble in organic solvents associated with kerogen are collectively called bitumen.

Based on the Rock-Eval data (Tables 1, 2, 3), source rocks can be characterized using the cross plot of TOC versus Hydrogen İndex (HI) [11]. This plot showed that the Naokelekan samples (well Bj-1, Biji Oil field) have a fair to good oil source with mixed gas source. On the other hand, (well Taq Taq-1, Taq Taq Oil field) is a gas source; while well Jk-1 (Jabal Qand Oil field) has a fair oil source (Fig.2).

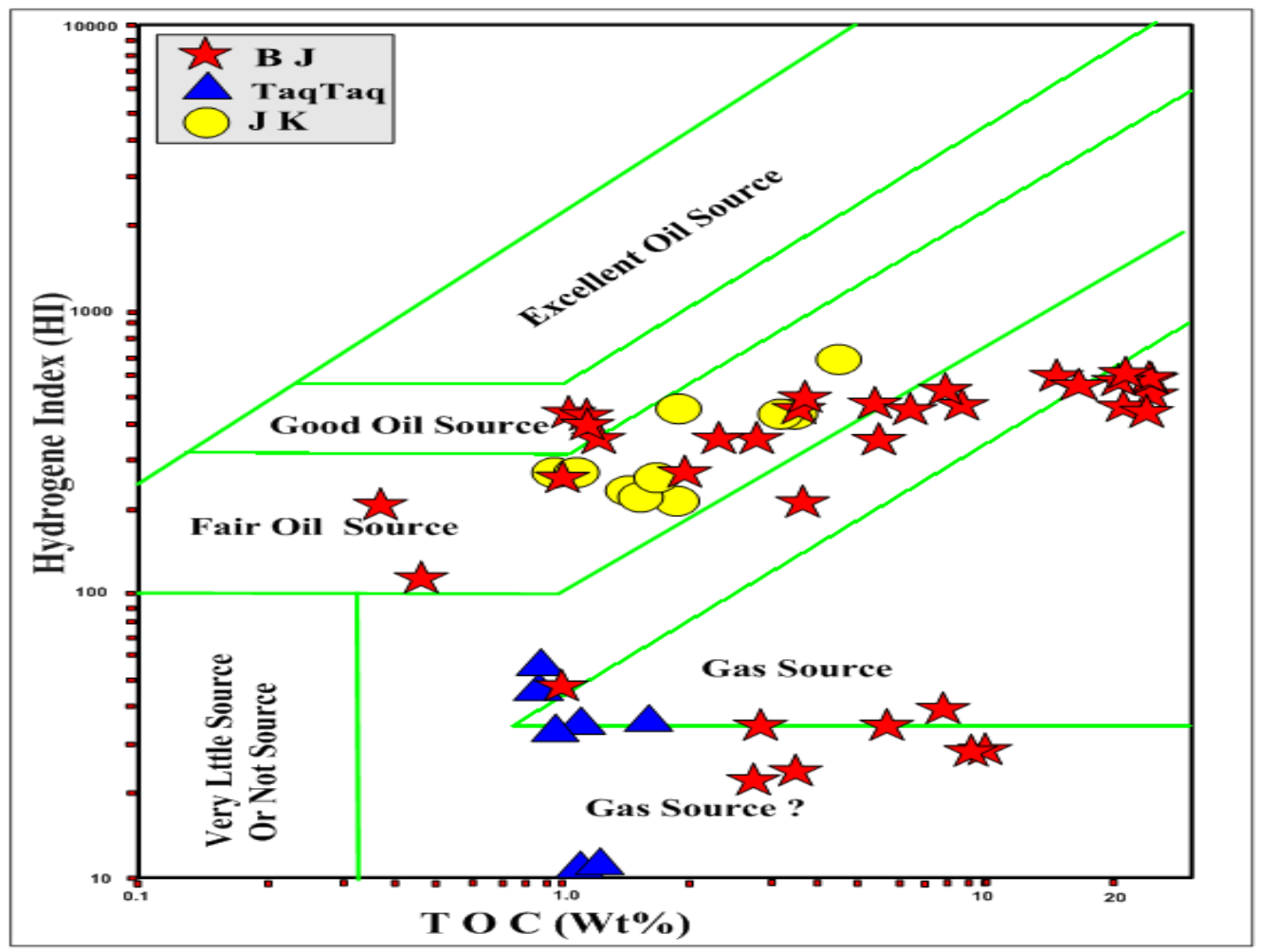

Fig-2. Source rock characterization based on HI versus TOC apdated after Jackson, et al. [11]

Furthermore, the cross plot of TOC versus S2, (Fig.3) indicates that the kerogen of the Naokelekan Formation (well $\mathrm{Bj}-1$ ), is excellent to poor, Taq Taq-1 well is fair to good and Jk-1 well is refer excellent to fair.

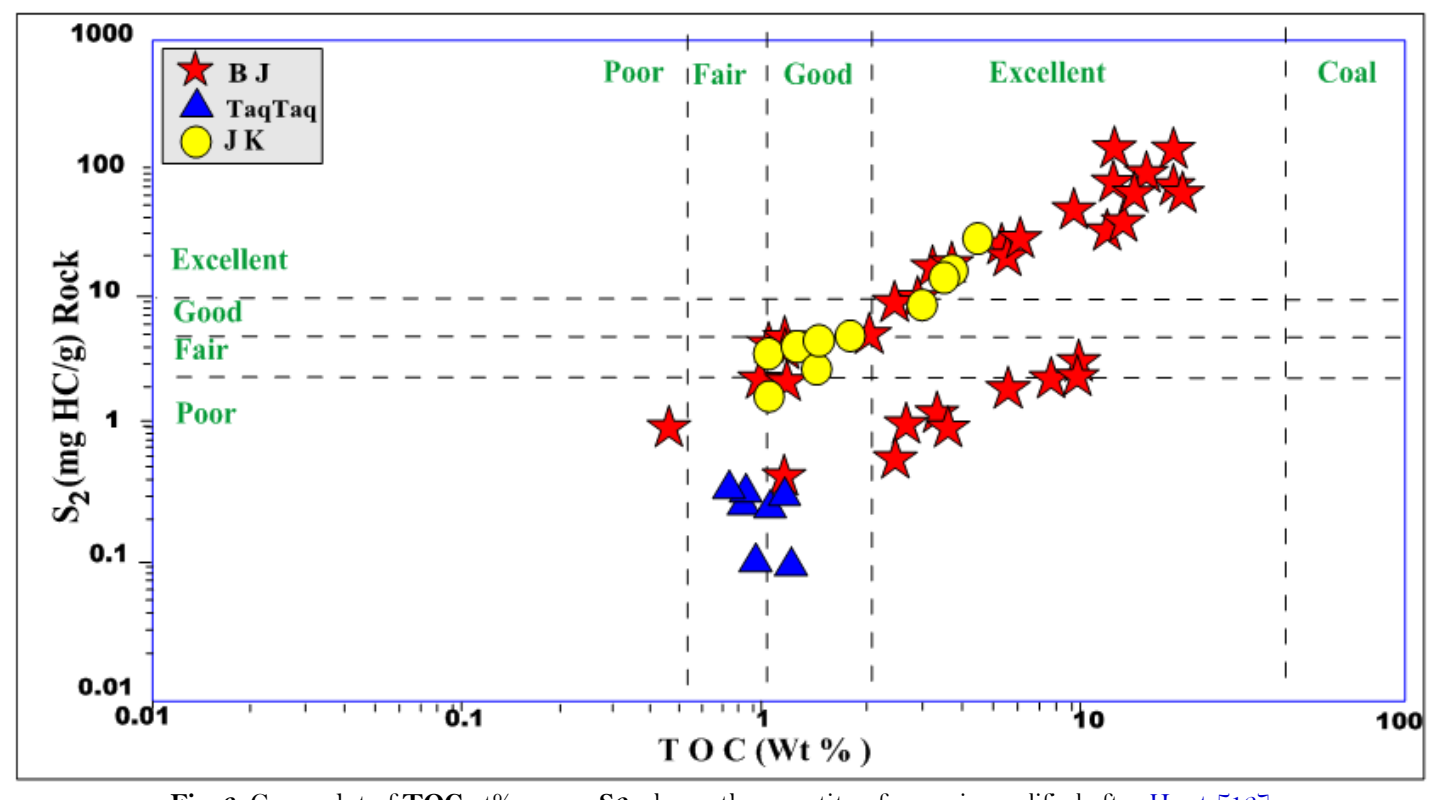

Fig-3. Cross plot of $\mathbf{T O C} w \mathrm{t} \%$ versus $\mathbf{S} \boldsymbol{2}$, shows the quantity of organic modified after Hunt [12] 
The Hydrogen İndex (HI) versus Oxygen İndex (OI) based on Rock-Eval pyrolysis data (Tables 1, 2, 3), can be plotted on a modified van Krevelen diagram and interpreted [9]. It is observed from (Fig.4) that Type-I, II is the dominant organic matter in the $\mathrm{Bj}-1$ well with few sample as Type IV kerogen, while Taq Taq-1 and Jk-1 well rock samples are represented by Type-IV and -I/II kerogens.

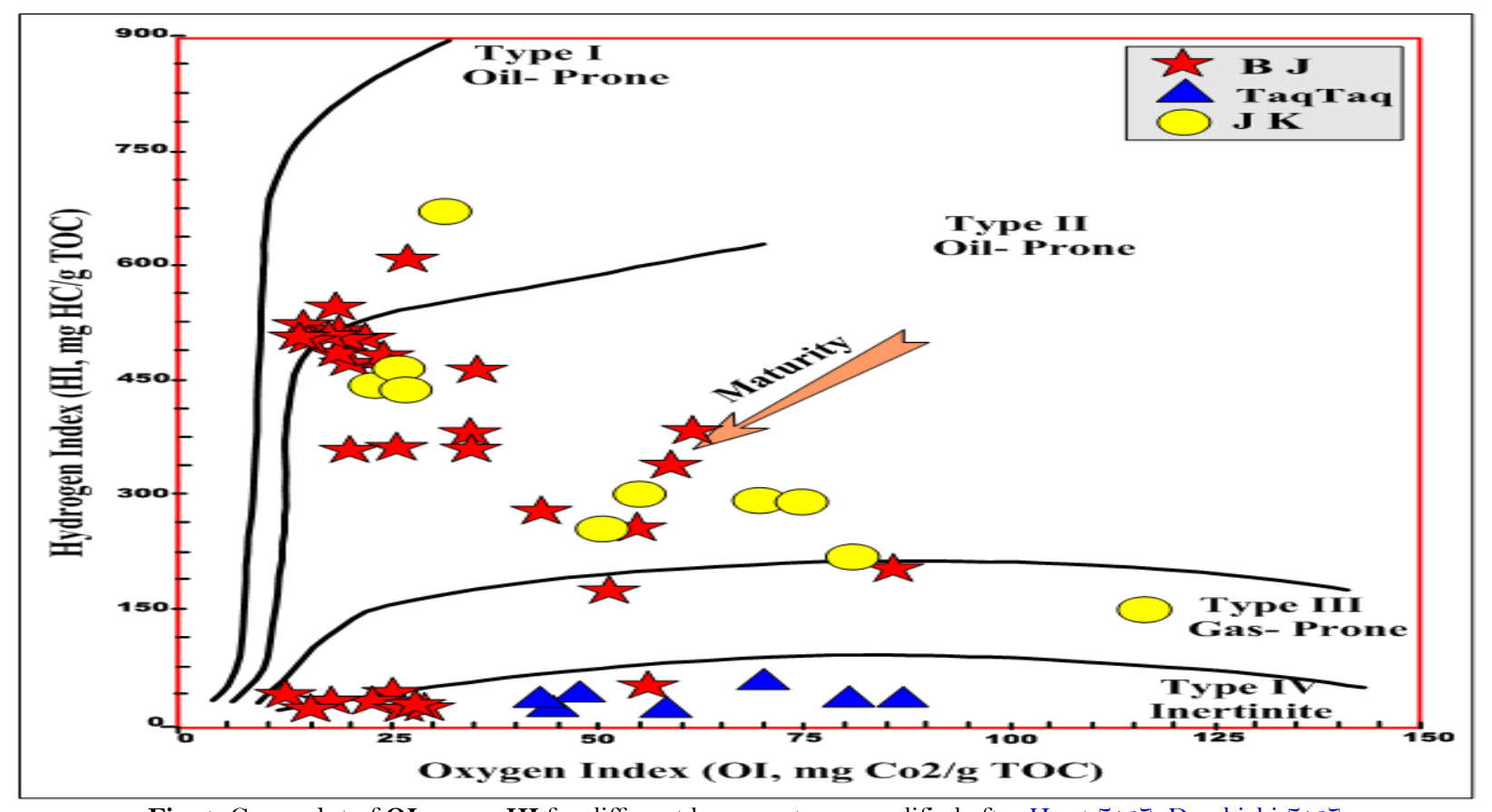

Fig-4. Cross plot of OI versus HI for different kerogen types modified after Hunt [12]; Dembicki [13]

\subsection{Thermal Maturity}

A source rock that has the possibility of producing a great amount of hydrocarbons is defined as mature. A source rock that lacks this ability is defined as immature, and that which passed the time of significant generation is define as over mature source rock [12].

The temperature at which the greatest amount of S2 is produced during pyrolysis is called Tmax [13]. To avoid the influence of OI, we commonly used the cross plot of HI versus Tmax to determine thermal maturity and kerogen type [12]. (Fig.5) confirms that the Naokelekan formation in the Bj-1 well and Taq Taq-1 well is immature and lies within Type-II \III, while Jk-1 well samples are immature to over mature Type-II with few samples refer Type IV kerogens.

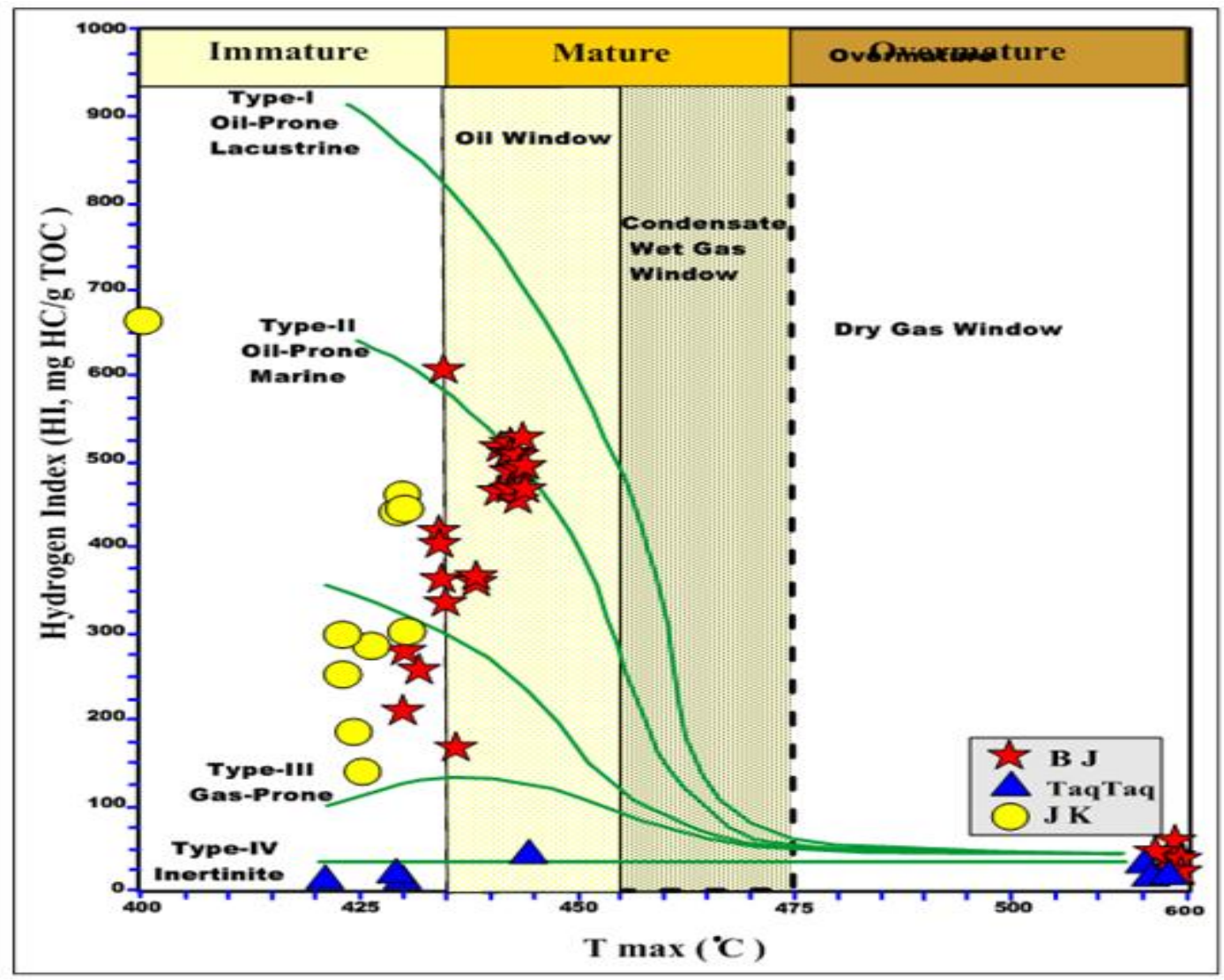

Fig-5. Hydrogen index (HI) versus $\mathbf{T}_{\max }$ from Espitalié, et al. [14]; Dembicki [13]

On the other hand, the thermal maturity of organic matter can be assessed through the combined relationship between Tmax and the calculated Production İndex (PI) [15]. The cross plot of Tmax versus PI (Fig.6) shows that Bj-1 well samples are range from mature to over mature, while Taq Taq-1 well are marginally mature to over mature. The majority of samples for Jk-1 well are immature. 


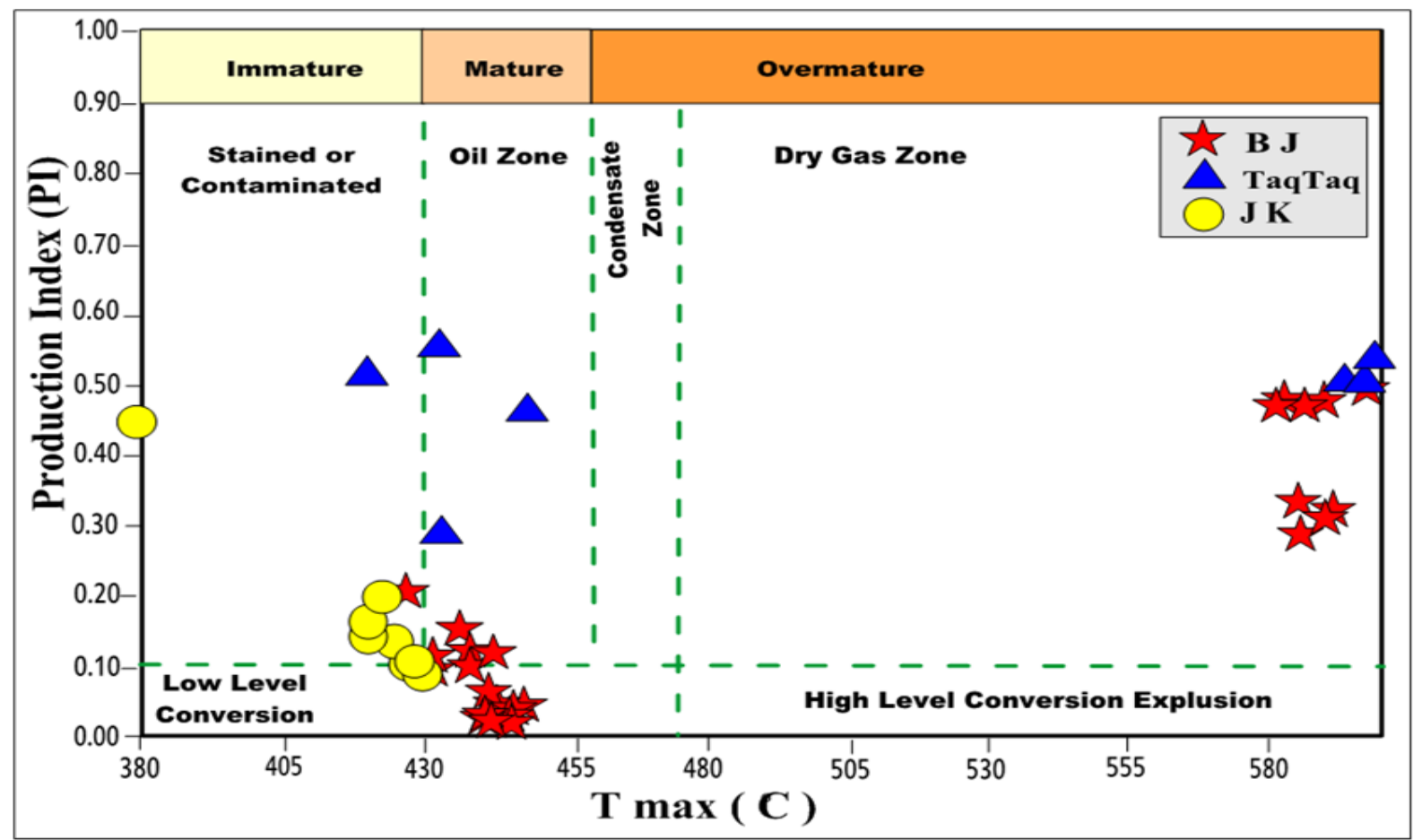

Fig-6. $\mathbf{T}_{\max }$ versus PI modified after Langford and Blank-Valleron [15]; Espitalié, et al. [14]

\subsection{Migrated Hydrocarbons}

Nonindigenous hydrocarbons can be detected, if $\mathrm{S}_{1}$ is high and the TOC is low [15]. Therefore, TOC versus $\mathrm{S}_{1}$ diagram have been used to separates migrated from non-migrated hydrocarbons for the cutting samples taken from selected wells (Fig.7). Thus all the analyzed samples plot in indigenous hydrocarbons field, reflecting no external contribution of migrated hydrocarbons to the analyzed sample for selected wells.

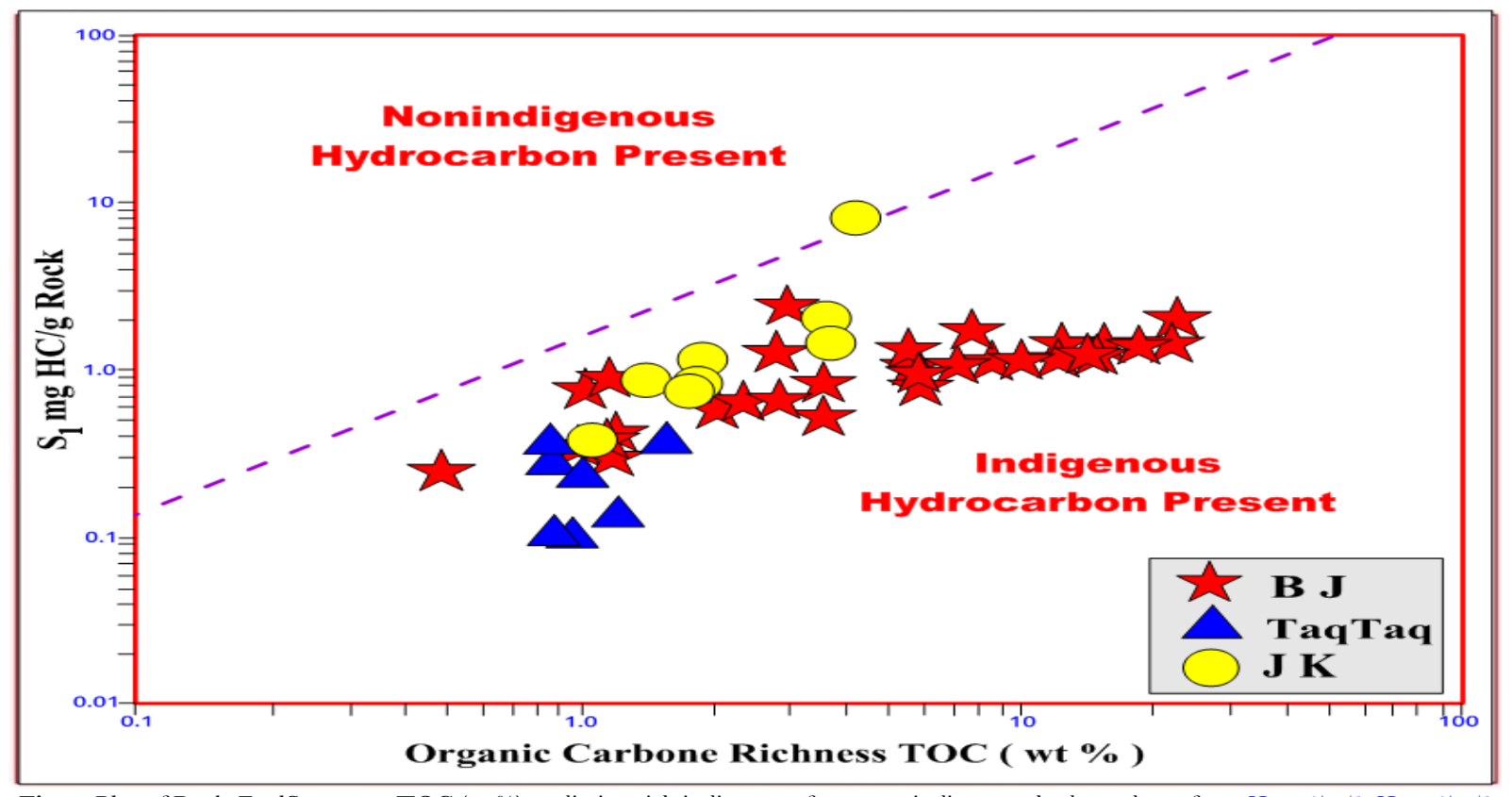

Fig-7. Plot of Rock-EvalS1 versus TOC (wt \%) to distinguish indigenous from non-indigenous hydrocarbons from Hunt [16]; Hunt [12]

\section{Conclusions}

Rock-Eval pyrolysis data of Naokelekan formation indicate a wide variation of source richness and quality, but all samples contain various quantities of Type-I/II, Type-II (oil prone) and Type-IV (gas-prone) organic matter among the Bj-1, Taq Taq-1 and Jk-1 wells. HI for Bj-1 well (24-605 mg HC/g TOC), Taq Taq-1 (9-48 mg HC/g TOC) and (147-673 $\mathrm{mg} \mathrm{HC} / \mathrm{g}$ TOC) Jk-1 which imply that the studied samples contain mostly Type II $\backslash$ III for Bj1, Taq Taq-1 and Type II with minor Type IV. HI- OI diagram shows that kerogen type is mainly Type-I $\backslash$ II for Bj-1, Type-IV with Type-I/II for Taq Taq-1 and Jk-1 wells, while HI-T $\max$ diagram classifies that the Naokelekan formation in the $\mathrm{Bj}-1$ well and Taq Taq-1 well is immature and lies within Type-II $\backslash$ III, while Jk-1 well samples are immature to over mature Type-II with few samples refer Type IV kerogen.

\section{References}

[1] J. K. Pitman, D. Steinshouer, and M. D. Lewan, "Petroleum generation and migration in the mesopotamian Basin and zagros fold belt of Iraq result from a basin-modeling study," Gulf Petrolink Bahrain, vol. 9, pp. 41-72, 2004. View at Google Scholar

[2] B. P. Tissot and D. H. Welte, Petroleum formation and occurrence: A new approach to oil and gas exploration, 2nd ed. vol. 699. Berlin: Springer-Verlag, 1984.

T. Buday, The regional geology of Iraq: Stratigraphy and palaeogeography. Baghdad: State Organization for Minerals, 1980. A. S. Al-Sharhan and A. E. M. Nairn, Sedimentary basins and petroleum geology of the Middle East. Amsterdam: Elsevier, 1997.

P. R. Sharland, R. Archer, D. M. Cassey, R. B. Davies, S. H. Hall, A. P. Heward, A. D. Horbery, and M. D. Simmons, Arabian plate sequence stratigraphy, 371 ed. Bahrain: Gulf PetroLink, 2001.

[6] A. A. M. Aqrawi, J. C. Goff, A. D. Horbury, and F. N. Sadooni, The petroleum geology of Iraq. Beaconsfield: Scientific Press Ltd, 2001. R. M. Pollastro, A. S. Karshbaum, and R. G. Viger, "Map showing geology, oil and gas fields, and geologic provinces of the Arabian Peninsula," US Geological Survey, Open File Report 97-470B1999. 
[8] R. C. Bellen, H. V. Van Dunnington, R. Wetzel, and D. M. Morton, Luxique stratigraphique international. Iraq, Paris: Asie, Fascicule10a, 1959

[9] K. E. Peters and M. R. Cassa, "Applied source-rock geochemistry. In: Magoon, L.B., Dow, W.G. (Eds.), The petroleum systemfrom source to trap," American Association of Petroleum Geologists Memoir, vol. 60, pp. 93-120, 1994.

[10] B. P. Tissot and D. H. Welte, Petroleum formation and occurrence, 2nd ed. Berlin, Heidelberg: Springer-Verlag, 1984.

$[11] \quad$ K. S. Jackson, P. J. Hawkins, and A. J. R. Bennett, "Regional facies and geochemical evaluation of Southern denison trough," APEA Journal, vol. 20, pp. 143-158, 1985. View at Google Scholar $\mid$ View at Publisher

[12] J. Hunt, Petroleum geochemistry and geology. NewYork, USA: Freeman and Company, 1996

[13] H. J. Dembicki, "Three common source rock evaluation errors made by geologists during prospect or play appraisals," American Association of Petroleum Geologists Bulletin, vol. 93, pp. 341-356, 2009. View at Google Scholar | View at Publisher

[14] J. Espitalié, J. L. La Porte, M. Madec, F. Marquis, P. Leplat, J. Paulet, and A. Boutefeu, "Rapid method for the characterization of source rocks, their oil potential and their degree of evolution," Journal of the French Institute of Oil, vol. 32, pp. 23-42, 1977. View at Google Scholar

[15] F. F. Langford and M. M. Blank-Valleron, "Interpretation of rock-eval pyrolysis data using pyrolyzable hydrocarbons vs. total
organic carbon," American Associations of Petroleum Geologists Bulletin, vol. 74, pp. 799-804, 1990. View at Google Scholar View at Publisher

[16] J. M. Hunt, Petroleum geochemistry and geology vol. 743. New York: W. H. Freeman and Company, 1995. 